\title{
Analisis Lingkungan Sekitar Tambang Nikel Terhadap Kualitas Ternak Sapi Pedaging di Kabupaten Halamahera Timur
}

\section{Environment Assessment Around Nickel Mining on Beef Cattle Quality in East Halmahera District}

\author{
Gunawan $^{1}$, R.Priyanto ${ }^{2}$, Salundik ${ }^{2}$ \\ ${ }^{1}$ Mahasiswa Ilmu Produksi dan Teknologi Peternakan Sekolah Pascasarjan Institut Pertanian Bogor. \\ ${ }^{2}$ Fakultas Peternakan Institut Pertanian Bogor \\ Alamat: Jl. Agatis, Gedung Fakultas Peternakan IPB, Kampus IPB Darmaga Bogor. \\ Correspondence author : ghunhatari@gmail.com
}

\begin{abstract}
Continuous activity in nickel mining has resulted in steadily growing numbers of contaminants which influence the environment. Cattle rising nickel mining in East Halmahera are exposed to high contamination. This study was conducted to assess the presence of heavy metal contamination on soil, water, grass and animal products such as liver and meet. The method used were survey and case study. The parameters measured were the heavy metal content (Pb), Cadmium (Cd), Arsenic (As) and Mercury (Hg) in soil, water, grass and sample of cattle liver and meat. The samples were analyzed using AAS (Atomic Absorption Spectrophotometry) method. Thedata obtained were analyzed descriptively and t-test was used to asses the difference results of all parameters measured from two locations. The results showed that $\mathrm{Pb}$ in water and outside mining location were 0.1367 and $0.0770 \mathrm{ppm}$, respectively. Hg concentration in soil, water, grass, liver and meet callte raised around mining location were 17.8725, $0.0447,6.6925,7.4910$ and $4.7210 \mathrm{ppb}$, respectively. The water around mining was contaminated with $\mathrm{Pb}$. The contaminanion of $\mathrm{Hg}$ on soil, water and grass around mining areas, and also the liver and meat samples of cattle were exceeded the maximum standard that could be tolerated.
\end{abstract}

Keywords: heavymetal,mining nickel,contamination, beef cattle.

\section{PENDAHULUAN}

Eksploitasi sumber daya alam seperti industri pertambangan merupakan salah satu industri yang secara finansial sangat menguntungkan untuk perekonomian negara karena memiliki daya jual yang tinggi di pasaran global. Namun setiap eksploitasi sumber daya alam ini dapat menimbulkan dampak terhadap lingkungan, baik secara fisik maupun sosial (Purwantari 2007).

Kegiatan pertambangan pada umumnya dilakukan di kawasan hutan dapat menyebabkan kerusakan lingkungan secara keseluruhan dalam bentuk pencemaran air, tanah dan udara. Hal ini dibenarkan Susilo (2003) yang menyatakan bahwa pencemaran lingkungan adalah suatu keadaan yang terjadi karena perubahan kondisi tata lingkungan yaitu, tanah, udara, dan air yang tidak menguntungkan bagi kehidupan manusia, hewan, dan tumbuhan yang disebabkan oleh kehadiran benda-benda asing seperti sampah, limbah industri, minyak, logam berat yang berbahaya dari aktifitas manusia dan mengakibatkan lingkungan tidak berfungsi seperti semula.

Perusahaan pertambangan yang berada di Kabupaten Halmahera Timur merupakan salah satu pertambangan nikel yang terbesar di Maluku Utara dengan jumlah produksi 8,205.411,00 metrik ton per tahun (BPS 2012). Hal ini menunjukan bahwa semakin besar produksi maka semakin besar pula limbah yang akan dihasilkan, sehingga dapat mencemari lingkungan sekitar tambang. Salah satu proses pembuangan limbah pertambangan dalam bentuk tailing. Menurut Pohan et al.(2007) tailing merupakan satu jenis limbah yang dihasilkan oleh kegiatan tambang dan kehadirannya dalam dunia pertambangan tidak bisa dihindari. Tailing mengandung logam-logam berat dalam kadar yang cukup mengkhawatirkan. Menurut WALHI 2006 mengatakan bahwa pembuangan tailing yang besar dapat merusak lingkungan. Hal ini dapat menyebabkan terjadinya pencemaran pada tanaman dan hewan yang hidup disekitar lingkungan tambang.

Lingkungan sekitar pertambangan dapat menjadi penyebaran utama dari logam berat, hal ini dapat menyebabkan menurunnya kualitas tanah, air dan rumput. Namun demikian rumput yang hidup dan tumbuh di daerah sekitar tambang dapat memberikan peluang bagi masyarakat untuk menjadikannya sebagai lahan pasture (ladang pengembalaan) untuk ternaknya. Namun, dilain pihak kemungkinan terjadi akumulasi logam berat pada tanah, air, dan rumput yang dapat berdampak akumulasi logam berat pada daging dan organ hewan yang diternakan disekitar tambang. Taggart et al. (2011) daging domba dan babi hutan yang hidup di areal pertambangan di temukan kadar logam berat $\mathrm{Pb}$ yang berlebihan.

Salah satu jalur masuknya logam berat yang dapat 
menyebabkan gangguan kesehatan pada manusia melalui asupan subtansi tokasik yang bersumber dari makan yang dikonsumsinya. Palar (2004), menyebutkan bahwa logam berat masuk ke dalam tubuh makhluk hidup melalui rantai makanan, pernapasan atau penetrasi melalui kulit. Daging merupakan salah satu bahan pangan yang diminati banyak orang, namun di dalamnya memungkinkan membawa sejumlah substansi toksis. Bahri (2008), menyatakan bahaya atau hazard yang berkaitan dengan keamanan pangan asal hewan dapat terjadi pada setiap mata rantai, mulai dari praproduksi di produsen, pascaproduksi sampai produk tersebut didistribusikan dan disajikan kepada masyarakat. Pada sebagian produk daging ada yang terkontaminasi logam berat dalam jumlah yang sedikit. Menurut Khalafalla et al. (2011) walaupun jumlahnya cukup kecil di dalam daging, namun pada bagian tertentu pada tubuh ternak yang juga sering dikonsumsi misalnya pada organ hati dan ginjal, sering menunjukkan konsentrasi substansi toksik yang cukup tinggi.

Penelitian ini bertujuan untuk mengkaji kondisi lingkungan seperti tanah, air, rumput dan keamanan pangan ternak berupa hati dan daging sapi pedaging dengan cara mendeteksi adanya residu logam berat timbal $(\mathrm{Pb})$, cadmium $(\mathrm{Cd})$, arsen (As), merkuri $(\mathrm{Hg})$, yang berada di sekitar tambang nikel dan di luar tambang Kabupaten Halmahera Timur.

\section{METODE PENELITIAN}

\section{Waktu dan Tempat}

Penelitian dilakukan padabulan Februari hingga Juli 2014 di Kecamatan Wasile dan Kecamatan Wasile Timur, Kabupaten Halmahera Timur dan Laboratorium Ilmu Nutrisi dan Pakan, Fakultas Peternakan Institut Pertanian Bogor.

\section{Materi}

Alat dan Bahan

Penelitian ini menggunakan ternak sapi pedaging yang digembalakan disekitar tambang nikel dan di luar tambang sebanyak 6 ekor ternak. Peralatan yang digunakan yaitu alat tulis, kamera, timbangan electrik, Coolbox, botolHDPE, labu $50 \mathrm{ml}$, hotplate,erlenmeyer ukuran 125 $\mathrm{ml}$, Spektrometri Serapan Atom (SSA), dan bahan yang digunakan yaitu tanah, air, rumput, hati dan daging, asam perkhlorat, aquades, dan asam nitrat $\left(\mathrm{HNO}_{3}\right)$.

\section{Prosedur Penelitian}

Pengambilan sampel pada penelitian ini dibagi menjadi dua bagian yaitu lingkungan (tanah, air, rumput) padang penggembalaan dan produk peternakan (hati, daging) yang diperoleh dari Tempat Potong Hewan (TPH). Pada setiap sampel tanah, air, rumput, hati, dan daging di ambil sebanyak 300 gram dengan lokasi yang berbeda yaitu sekitar tambang nikel (Wasile) dan di luar tambang (Wasile Timur). Setiap perlakuan terdiri dari tiga ulangan. Kemudian sampel dianalisis di laboratorium menggunakan metode Spektrometri Serapan Atom (SSA).

\section{Peubah yang diamati}

Peubah yang diamati dalam penelitian ini yaitu cemaran kandungan logam berat timbal $(\mathrm{Pb})$, cadmium
$(\mathrm{Cd})$, arsen (As), dan merkuri ( $\mathrm{Hg})$ yang terdapat pada lingkungan dan bagian produk ternak yaitu tanah, air, rumput, hati dan daging sapi pedaging yang digembalakan di sekitar tambang dan di luar tambang dengan menggunakan metode Spektrometri Serapan Atom (SSA). Spektrometri merupakan suatu metode analisis kuantitatif yang pengukurannya berdasarkan banyaknya radiasi yang dihasilkan atau yang diserap oleh spesi atom atau molekul analit. Salah satu bagian dari spektrometri ialah Spektrometri Serapan Atom (SSA), merupakan metode analisis unsur secara kuantitatif yang pengukurannya berdasarkan penyerapan cahaya dengan panjang gelombangtertentu oleh atom logam dalam keadaan bebas (Skoog et. al., 2000).

\section{Analisis Data}

Analisis hasil penelitian ini dilakukan dengan cara membandingkan kandungan logam berat pada lingkungan maupun produk peternakan dengan Standar yang berlaku. Pada lokasi yang berbeda antara sekitar tambang nikel (Wasile) dan di luar tambang (Wasile Timur) dilakukan dengan mengunakan Uji-t

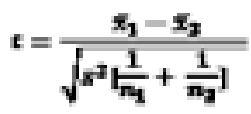

di mana :

$$
\begin{aligned}
& \mathrm{n} \neg \mathrm{i}=\text { jumlah pengamatan } \\
& \mathrm{i} \quad=\text { rataan sampel } \\
& \mathrm{s} \neg \mathrm{i}=\text { standar deviasi yang diperkirakan }
\end{aligned}
$$
dengan

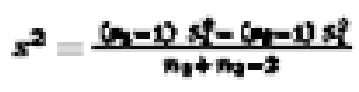

\section{HASIL DAN PEMBAHASAN}

\section{Cemaran Logam Berat pada Lingkungan}

Salah satu penyebab terjadinya percemaran lingkungan yang berasal dari limbah akibat dari akitivtas manusia seperti industri perusahan, pertanian, dan rumah tangga. Hal ini akan berdampak terhadap kehadiran bandabenda asing yang mencemari lingkungan salah satunya adalah logam berat. Cemaran logam pada lingkungan dapat mempengaruhi metabolisme pada tanah, air dan rumput yang berada di sekitar tambang, hal ini dapat terlihat pada tabel-tabel dibawah ini.

Hasil analisis laboratorium (Tabel 1)menujukan bahwa kosentrasi logam berat $\mathrm{Pb}, \mathrm{Cd}$, dan As pada tanah di sekitar tambang nikel dan di luar tambang masih berada dibawah ambang batas yang ditetapkan. Sedangkan kisaran kandungan logam berat $\mathrm{Hg}$ pada tanah di sekitar tambang nikel melebihi ambang batas kritis. Keberadaan kandungan logam berat merkuri $(\mathrm{Hg})$ pada tanah yang ada disekitar tambang nikel dikarenakan penggunaan merkuri dalam proses pemisahan bijih logam dengan jumlah yang besar, sehingga dapat menghasilkan limbah merkuri lebih tinggi dan berdampak pada lingkungan sekitarnya. Hal ini juga dinyatakan oleh Mirdat et al. (2013) tingginya kandungan logam berat merkuri pada tambang emas dikarenakan penggunaan merkuri pada saat pengolahan mencapai 
Tabel 1 Rata-rata kandungan logam berat pada tanah di sekitar tambang nikel dan di luar tambang

\begin{tabular}{lccc}
\hline \multirow{2}{*}{ Logam Berat } & \multicolumn{2}{c}{ Kecamatan } & Ambang Batas \\
\cline { 2 - 3 } & Wasile 1 & Wasile Timur 2 & Wei \& Yang (2010) \\
\hline $\mathrm{Pb}(\mathrm{ppm})$ & $1.1397 \pm 0.301$ & $0.6650 \pm 0.168$ & 2.60 \\
$\mathrm{Cd}(\mathrm{ppm})$ & $0.0407 \pm 0.003$ & $0.0405 \pm 0.011$ & 0.097 \\
$\mathrm{As}(\mathrm{ppb})$ & $0.0417 \pm 0.005 \mathrm{a}$ & $0.0275 \pm 0.001 \mathrm{~b}$ & 1.21 \\
$\mathrm{Hg}(\mathrm{ppb})$ & $17.8725 \pm 1.511 \mathrm{a} *$ & $0.0545 \pm 0.009 \mathrm{~b}$ & 0.3 \\
\hline
\end{tabular}

Keterangan : a Angka-angka pada baris yang sama yang diikuti oleh huruf yang sama tidak berbeda nyata pada taraf uji 5\%,1 tambang nikel, 2 luar tambang, *) melebihi ambang batas; $\mathrm{Pb}=$ Timbal; $\mathrm{Cd}=\mathrm{Cadmium}$; $\mathrm{As}=\mathrm{Arsen} ; \mathrm{Hg}=$ Merkuri

500 cc per tromol persatu kali pengolahan, sehingga limbah yang dihasilkan mengandung logam merkuri yang cukup tinggi dan dapat berdampak pada lahan sekitarnya baik secara langsung maupun tidak langsung. Selain itu jarak tambang nikel tidak jauh dari aktifitas padang pengembalaan sehingga dapat mempengaruhi keberadaan merkuri pada lingkungan sekitar. Widowati et al. (2008) tersebarnya logam berat merkuri (Hg) di tanah, perairan, dan udara bisa melalui berbagai jalur seperti pembuangan limbah industri secara langsung, baik limbah padat maupun limbah cair yang dibuang ke tanah,udara, dan air. Hal ini juga dinyatakan oleh Priyanto dan Prayitno(2006) pencemaran logam berat di lahan sekitar penambangan, industri perusahaan, dan pertanian akan sangat meningkatkan kandungan logam berat $\mathrm{Hg}$ didalam tanah karena residu maupun akibat tindakan dari kegiatan tersebut akan dibuang ataupun ditimbun didalam tanah. Dalam jumlah yang sedikit tanah dapat mengurai logam berat, namun secara terus menerus tanah akan terakumulasi dan tercemar logam berat.

Kosentrasi $\mathrm{Pb}$ pada kedua lokasi penelitian (Tabel 2) di sekitar tambang nikel dan di luar tambang bahwa air yang di konsumsi ternak melebihi batas maksimum toleransi. Hal ini karena air yang dikonsumsi oleh ternak di sekitar tambang nikel adalah air yang mengalir dan sudah tercemar oleh logam berat akibat dari aktifitas pertambangan. Kontaminasi logam berat pada bersumber melalui sidmen tanah dan aliran yang melewati tempat-tempat pembuangan limbah industri kemudian mengalir menuju ke hilir air. Sedangkan logam berat $\mathrm{Pb}$ pada air di luar tambang disebabkan oleh aktifitas manusia di lahan pertanian. Air drainase pertanian yang mengandung pestisida, pupuk dan limbah dari kegiatan industri dapat memasok sejumlah besar anion organik dan logam berat pada air dan sedimen (EC 2002). Logam berat $\mathrm{Cd}$ dan As pada air di luar tambang tidak terdetaksi adanya kandungan logam berat $\mathrm{Cd}$, sama halnya dengan kandungan logam berat As dikedua lokasi tidak terdetaksi keberadaan oleh alat. Hal ini karena standar yang digunakan oleh alat SSA sebesar $<0.1 \mathrm{ppb}$.
Logam berat $\mathrm{Hg}$ mencapai batas maksimum toleransi mineral pada air minum yang dikonsumsi oleh ternak sapi pedaging yang digembalakan di sekitar tambang nikel. Tingginya kosentrasi $\mathrm{Hg}$ disebabkan karena dalam proses pengolahan bijih membutuhkan aliran air untuk pemisahan batuan halus dengan campuran merkuri dan nikel menggunakan tromol. Menurut Sualang (2001) teknik amalgamasi dilakukan dengan cara mencampur batuan yang mengandung logam emas dan merkuri dengan menggunakan tromol (Sualang, 2001). Dalam kegiatan tersebut dibutuhkan aliran air untuk memisahkan batuan halus dan amalgam (campuran merkuri dan emas) yang dialirkan ke kolam penampungan limbah (tailling) (Lingkubi, 2004). Keberadaan kandungan logam berat (Tabel 1) pada tanah tercemar logam berat $\mathrm{Hg}$, sehingga dapat mempengaruhi logam berat pada air. Mendie (2005) bahwa air dapat memperoleh kontaminan dari aktivitas manusia (misalnya aktivitas dalam kegiatan industri) dan hewan serta aktivitas biologis lainnya. Air memiliki sifat yang sangat unik karena polaritas dan ikatan hydrogen yang dimiliki mampu melarutkan, menyerap atau menyimpan senyawa yang berbeda (WHO 2007). sedangkan logam berat $\mathrm{Hg}$ pada air di luar tambang tidak terdetaksi keberadaan oleh alat. Hal ini karena standar yang digunakan oleh alat SSA sebesar $<0.1 \mathrm{ppb}$.

Salah satu jalur masuk logam berat dalam tubuh ternak adalah melalui makanan yang dikonsumsi. Sama halnya dengan manusia, kontaminasi logam berat pada pakan ternak dapat mempengaruhi produksi pada ternak,seperti turunnya bobot badan, menghambat pertumbuhan, penyakit infeksi dan kematian. Hal ini sejalan dengan Zainal Arifin (2008) keracunan logam pada hewan dapat terjadi melalui injeksi, air minum maupun melalui pakan dan dapat mempengaruhi produksi, yaitu penurunan bobot badan, hambatan pertumbuhan, peka terhadap penyakit infeksi, dan kematian. Rumput merupakan sumber makanan utama bagi ternak sehingga keberadaan logam berat dalam rumput dapat memicu pengendapan sejumlah logam berat dalam tubuh ternak.

Konsentrasi $\mathrm{Pb}, \mathrm{Cd}$ dan As (Tabel 3) pada

Tabel 2 Rata-rata kandungan logam berat pada air di sekitar tambang nikel dan di luar tambang nikel

\begin{tabular}{lccc}
\hline \multirow{2}{*}{ Logam Berat } & \multicolumn{2}{c}{ Kecamatan } & \multicolumn{2}{c}{ Ambang Batas } \\
\cline { 2 - 4 } & Wasile 1 & Wasile Timur2, 2000$)$ & 0.01 \\
\hline $\mathrm{Pb}(\mathrm{ppm})$ & $0.1367 \pm 0.023^{*}$ & $0.0770 \pm 0.034$ & 0.05 \\
$\mathrm{Cd}(\mathrm{ppm})$ & $0.0010 \mathrm{a}$ & $\mathrm{td}$ & 0.05 \\
$\mathrm{As}(\mathrm{ppb})$ & $\mathrm{td}$ & $\mathrm{td}$ & 0.05 \\
\hline
\end{tabular}


Tabel 3 Rata-rata kandungan logam berat pada rumput di sekitar tambang nikel dan di luar tambang

\begin{tabular}{lccc}
\hline Logam Berat & Kecamatan & Ambang Batas \\
& Wasile1 & Wasile Timur2 & (NRC, 2000) \\
\hline $\mathrm{Pb}(\mathrm{ppm})$ & $0.9737 \pm 0.223 \mathrm{a}$ & $0.2615 \pm 0.062 \mathrm{~b}$ & 1.00 \\
$\mathrm{Cd}(\mathrm{ppm})$ & $0.0347 \pm 0.022$ & $0.0267 \pm 0.015$ & 10 \\
$\mathrm{As}(\mathrm{ppb})$ & $\mathrm{td}$ & $\mathrm{td}$ & $\mathrm{tb}$ \\
$\mathrm{Hg}(\mathrm{ppb})$ & $6.6925 \pm 2.802 \mathrm{a} *$ & $0.0590 \pm 0.002 \mathrm{~b}$ & 2.00 \\
\hline
\end{tabular}

Keterangan: :aAngka-angka pada baris yang sama yang diikuti oleh huruf yang sama tidak berbeda nyata pada taraf uji $5 \%, 1$ tambang nikel, 2 luar tambang, *) melebihi ambang batas, $\mathrm{td}=$ tidak terdeteksi, $\mathrm{tb}=$ belum ada batas toleransi, $\mathrm{Pb}=$ Timbal; $\mathrm{Cd}=$ Cadmium; As $=$ Arsen; $\mathrm{Hg}=$ Merkuri

rumput di sekitar tambang nikel dan di luar tambang, tidak melebihi angka maksimum toleransi mineral pada pakan. Logam berat yang tergolong toksik seperti $\mathrm{Hg}$ ditemukan sekitar tambang nikel. Tingginya konsentrasi $\mathrm{Hg}$ pada rumput dapat bersumber dari tanah dan air yang terkontaminsi pada logam berat $\mathrm{Hg}$ (Tabel 1, 2). Kontaminan ini diduga tersebar ke atmosfer melalui perantara angin dengan tingkat penghapusan logam dari tanah tergantung pada faktor-faktor seperti mineralogi buangan pertambangan, konsentrasi logam total, spesiasi dan ada atau tidak adanya ion bersaing (Onder et al. 2007; Gutiérrez Ginés et al. 2010; Bruce et al. 2003). Menurut NRC (2000) level toleransi Hg maksimum dalam pakan bentuk organik atau anorganik untuk sapi adalah $2 \mathrm{ppm}$. Logam $\mathrm{Hg}$ yang masuk melalui rute pakan dan saluran pencernaan akan diabsorpsi sekitar 3-8\% dari total $\mathrm{Hg}$ yang termakan. Rubio et al. (2006) menyatakan bahwa kandungan $\mathrm{Hg}$ yang terabsorpsi kedalam jaringan bisa bertahan selama periode waktu yang lama.

Pengikatan logam berat pada tanaman terjadi pada saat pembentukan senyawa kompleks melalui eksudat akar maka akar tanaman mengeluarkan sejumlah asam organik misalnya asam malat, sitrat, fumarat, fenolat yang menyebabkan $\mathrm{pH}$ di sekitar perakaran menurun. Akibatnya banyak senyawa dan ion logam berat menjadi terlarut sehingga terserap oleh akar tanaman. Logam berat yang terserap oleh akar selanjutnya akan tertranslokasi dan terakumulasi dalam akar, batang, daun, buah dan biji (Tan, 2000).

\section{Cemaran Logam Berat pada Daging dan Jeroan Sapi Pedaging}

Kontaminasi daging oleh logam berat dapat menjadi ancaman yang serius karena beberapa logam berat dapat bersifat toksik pada level tertentu. Logam berat dapat mengalami bioakumulasi dan biomagnifikasi sepanjang rantai makanan (Demirezen dan Uruc 2006). Kandungan logam berat pada organ ternak sapi pedaging yang digembalakan disekitar tambang nikel maupun di luar tambang ini sering kali terjadinya cemaran akibat dari aktivitas manusia.

Hasil penelitian (Tabel 4) menunjukkan bahwa cemaran logam $\mathrm{Pb}, \mathrm{Cd}$, dan As pada hati sapi potong yang mengacu pada standar SNI dan WHO masih berada dibawah ambang, sehingga hati sapi yang digembalakan di sekitar tambang maupun di luar tambang relatif aman dari cemaran $\mathrm{Pb}, \mathrm{Cd}$,dan As. Sedangkan kosentrasi logam berat Hg di sekitar tambang nikel melebihi ambang batas standar yang disyaratkan menurut BSN (2009).

Kandungan logam berat $\mathrm{Hg}$ paling banyak di temukan didalam organ hati pada ternak sapi yang dipelihara di sekitar tambang nikel. Hal ini karena ternak yang digembalakan berdekatan dengan aktiftas industri pertambangan $( \pm 800 \mathrm{~m})$ sehingga tanah, air, dan rumputter cemaran kandungan logam berat $\mathrm{Hg}$. Hal ini sejalan dengan Soeparno (2011) ternak dapat mengalami toksikosis $\mathrm{Hg}$ karena kontaminasi melalui udara, tanah, air dan dari $\mathrm{Hg}$ yang teringesti di dalam pakan. Ternak yang mengkontaminasi secara langsung melalui pakan dan air yang dikomsumsinya dan proses metabolisme logam $\mathrm{Hg}$ akan masuk ke jaringan tubuh ternak seperti hati. Selain itu, peran dari organ hati sebagai salah satu organ untuk detoksifikasi racun di dalam tubuh organisme. Stansley et al. (1991) menyatakan bahwa akumulasi Hg dapat terjadi di dalam organ-organ seperti hati, ginjal dan target jaringan termasuk otot. Level $\mathrm{Hg}$ dalam otot biasanya jauh lebih rendah daripada hati dan ginjal. Menurut Peterle (1991) hati dan ginjal merupakan organ tempat merkuri mengalami proses metabolisme dan proses

Tabel 4 Rata-rata kandungan logam berat pada hati sapi pedaging yang digembalakan di sekitar tambang nikel dan di luar tambang

\begin{tabular}{lccrr}
\hline & & Kecamatan & \multicolumn{2}{c}{ Standar MRL } \\
\cline { 2 - 4 } & Wogam Berat & Wasile Timur2 & SNI3 & WHO4 \\
\cline { 2 - 4 } $\mathrm{Pb}(\mathrm{ppm})$ & $0.0547 \pm 0.031$ & $0.0370 \pm 0.022$ & 1.00 & 0.10 \\
$\mathrm{Cd}(\mathrm{ppm})$ & $0.0257 \pm 0.001$ & $0.0240 \pm 0.002$ & 0.05 & $0.15-0.50$ \\
$\mathrm{As}(\mathrm{ppb})$ & $\mathrm{td}$ & $\mathrm{td}$ & 1.00 & 0.04 \\
$\mathrm{Hg}(\mathrm{ppb})$ & $7.4910 \pm 1.514 \mathrm{a}^{*}$ & $0.0197 \pm 0.018 \mathrm{~b}$ & 0.03 & 0.05 \\
\hline
\end{tabular}

Keterangan:aAngka-angka pada baris yang sama yang diikuti oleh huruf yang sama tidak berbeda nyata pada taraf uji 5\%1 tambang nikel, 2 luar tambang, 3 SNI 7378: 2009, 4 WHO (1996); *) melebihi ambang batas yang telah ditetapkan; $\mathrm{td}=$ tidak terdeteksi $\mathrm{Pb}=$ Timbal; $\mathrm{Cd}=$ Cadmium; $\mathrm{As}=$ Arsen; $\mathrm{Hg}=$ Merkuri; MRL (Maximum Residue Limit) 
Tabel 5 Rata-rata kandungan logam berat pada daging sapi pedaging yang di gembalakan di sekitar tambang nikel dan di luar tambang

\begin{tabular}{lcccc}
\hline \multirow{2}{*}{ Logam Berat } & \multicolumn{2}{c}{ Kecamatan } & \multicolumn{2}{c}{ Standar MRL } \\
\cline { 2 - 3 } & Wasile 1 & Wasile Timur2 & SNI 3 & WHO4 \\
\hline $\mathrm{Pb}(\mathrm{ppm})$ & $0.0417 \pm 0.012 \mathrm{a}$ & $0.0045 \pm 0.001 \mathrm{~b}$ & 1.00 & 0.10 \\
$\mathrm{Cd}(\mathrm{ppm})$ & 0.0120 & 0.0050 & 0.05 & $0.15-0.50$ \\
$\mathrm{As}(\mathrm{ppb})$ & $\mathrm{td}$ & $\mathrm{td}$ & 1.00 & 0.04 \\
$\mathrm{Hg}(\mathrm{ppb})$ & $4.7210 \pm 3.021^{*}$ & $0.0175 \pm 0.011$ & 0.03 & 0.05 \\
\hline
\end{tabular}

Keterangan:a Angka-angka pada baris yang sama yang diikuti oleh huruf yang sama tidak berbeda nyata pada taraf uji 5\%1 tambang nikel, 2 luar tambang, 3 SNI 7378: 2009, 4 WHO (1996); *) melebihi ambang batas yang telah ditetapkan; $\mathrm{td}=$ tidak terdeteksi $\mathrm{Pb}=$ Timbal; $\mathrm{Cd}=$ Cadmium; $\mathrm{As}=$ Arsen; $\mathrm{Hg}=$ Merkuri; MRL (Maximum Residue Limit)

ekskresi. Hal serupa dikatakan Hodgson dan Levi (1997) hati sebagai salah satu muara terakumulasi senyawa racun diantaranya logam berat karena seluruh hasil pencernaan akan diabsorpsi ke dalam hati melalui pembuluh darah, sehingga hati merupakan organ pertama yang berhubungan dan melakukan metabolisme terhadap racun yang terserap dalam saluran pencernaan. Secara alamiah hati memiliki enzim detoksifikasi yang mampu melakukan biotransformasi terhadap bahan-bahan toksik, dan banyak reaksi oksidasi yang dapat meningkatkan metabolisme sehingga mengakibatkan hati lebih mudah menyerap bahan-bahan toksik.

Hasil analisis (Tabel 5) $\mathrm{Pb}, \mathrm{Cd}$ dan As yang dilakukan pada daging sapi yang dipelihara di sekitar tambang nikel dan diluar tambang tidak melebihi ambang batas yang di tetapkan oleh BSN (2009). Hal ini sejalan dengan standar yang ditetapkan WHO maka daging sapi yang dipelihara di sekitar tambang nikel tidak melebihi ambang batas. Daging dari sapi yang dipelihara sekitar tambang nikel ditemukan $\mathrm{Hg}$ yang melebihi ambang batas,sehingga daging sapi tersebut tidak layak di konsumsi oleh masyarakat.

Masyarakat yang mengkonsumsi bahan pangan berupa daging yang tercemar kandungan logam berat $\mathrm{Hg}$ dalam jumlah yang banyak maka dapat berpengaruh terhadap tubuh karena menghambat kerja enzim dan menyebabkankerusakan sel. Sifat-sifat membran daridinding selakan rusak karena pengikatan dengan merkuri,sehingga aktivitas sel dapat terganggu. Menurut Widaningrum et al. (2007) kondisi yangakut dapat menyebabkan kerusakan perut dan usus,gagal kardiovaskular (jantung dan pembuluhnya), dangagal ginjal akut yang dapat menyebabkan kematian.

Kebaradaan logam berat $\mathrm{Hg}$ pada daging sapi dipengaruhi oleh keberadaan logam berat pada air dan rumput yang dikonsumsi. Ternak besar seperti sapi yang hidup pada suhu lingkungan sekitar $27-32^{\circ} \mathrm{C}$ dapat mengkonsumsi air sekitar 33.69-48.07 liter setiap harinya (NRC 2011). Aktivitas konsumsi air yang cukup besar, memungkinkan terakumulasi logam berat $\mathrm{Hg}$ dalam daging sapi.

\section{KESIMPULAN}

Hasil penelitian ini disimpulkan bahwa; (1) kondisi lingkungan berupa tanah, air, rumput dan kondisi keamanan pangan berupa hati dan daging sapi yang di gembalakan di sekitar tambang dan di luar tambang relatif aman dari cemaran logam berat $\mathrm{Cd}$, dan $\mathrm{As}$, namun, pada air di sekitar tambang dan di luar tambang tercemar logam berat $\mathrm{Pb}$ melebihi ambang batas yang ditetapkan. Sedangkan logam berat $\mathrm{Hg}$ pada tanah, air, rumput, hati dan daging sapi yang di gembalakan di sekitar tambang nikel melebihi ambang batas yang ditetapkan, maka perlu diwaspadai tecemarnya logam berat pada manusia. Sedangkan logam berat $\mathrm{Hg}$ di luar tambang tidak melebihi ambang batas, sehingga produk pangan berupa hati dan daging sapi layak dikonsumsi oleh masyarakat. (2) Penggunaan air baik disekitar maupun diluar tambang perlu diperhatikan karena kadar logam berat $\mathrm{Pb}$ melebihi ambang batas. (3) Lokasi di luar area tambang relatif lebih aman dari pencemaran $\mathrm{Hg}$ baik pada tanah, air, rumput, daging, maupun hati.

\section{SARAN}

Penelitian ini memberikan informasi gambaran keberadaan cemaran logam berat pada ternak sapi yang digembalakan disekitar tambang. Untuk penelitian lebih lanjut, perlu menganalisis logam berat pada darah, tulang, ginjal untuk mengatahui seberapa besar logam berat menyebar di dalam tubuh ternak sapi yang hidup dan merumput di sekitar tambang untuk mengetahui logam berat yang terserap di dalam tubuh ternak dan mendapatkan informasi mengenai jalur detoksifikasinya.

\section{UCAPAN TERIMA KASIH}

Terima kasih penulis ucapkan kepada Direktorat Jendral Pendidikan Tinggi (DIKTI) yang memberikan penulis kesempatan untuk melanjutkan studi dan Dr.Ir. Rudy Priyanto dan Dr.Ir. Salundik M.Si, selaku pembimbing yang telah memberikan dukungan selama membimbing dan teman-teman KARFAPALA UNKHAIR yang turut membantu penulis dalam melakukan penelitian serta semua pihak atas bantuannya sehingga penelitian ini berjalan dengan baik.

\section{DAFTAR PUSTAKA}

Anggorodi, 1989. Ilmu Makanan Ternak Umum. Jakarta (ID): PT Gramedia.

Bahri S. 2008. Beberapa aspek keamanan pangan asal ternak di indonesia .Pengembangan Inovasi Pertanian. 1 (3): 225-242.

Binggan Wei, Linsheng Yang (2010)A review of heavy metal contaminations in urban soils, urban road dusts 
andagricultural soils from China. Microchemical Journal 94 (2010) 99-107

[BPS] Balai Pusat Statistik Kabupaten Halmahera Timur 2012. Halmahera Timur dalam Angka.

Bruce S.L, Noller B.N, Grigg A.H, Mullen B.F, Mulligan D.R, Ritchie P.J, Currey N, Ng J.C. 2003. A field study conducted at Kidston gold mine, to evaluate the impact of arsenic and zinc from mine tailing to grazing cattle, In: Toxicology letters: Proceedings of the $9^{\text {th }}$ International Congress of Toxicology (ICT IX). South Molle Island Resort Conf Centre, Queensland pp: 23-34.

Diapari, D.2009. Dampak Pencemaran Timbal (Pb) Akibat Hujan Asam Terhadap Produksi Ternak Domba Lokal Jantan, Disertasi, Sekolah Pascasarjana Institut Pertanian Bogor.

Mendie U. 2005. The Nature of Water. In: The Theory and Practice of Clean Water Production for Domestic and Industrial Use. Lagos: Lacto-Medals Publishers, pp: $1-21$.

Mirdat, Yosep S,P, Isrun. 2013. Status Logam Berat Merkuri (Hg) Dalam Tanah Pada Kawasan Pengolahan Tambang Emas di Kelurahan Poboya Kota Palu. Jurnal Agrotekbis 1 (2) : 127-134, juni 2013.

[NRC] National Research Council. 2000. Nutrient Requirement of Beef Cattle. $7^{\text {th }}:$ 69-89. ISBN : 0-309-59241-0.

Palar. Heryando., 2004. Pencemaran dan toksikologi logam berat.Jakarta (ID): Rineka cipta. p. 78-86

Palar, Heryando. 2008. Pencemaran Dan Toksikologi Logam Berat. (ID) Rieneka Cipta. Jakarta.

Pickering W., (1980). Cadmium in the Enironment, John Wiley, New York.

Pohan P.M., Denni W. , Sabtanto J.S. , Asep. 2007 Penyelidikan Potensi Bahan Galian pada Tailing PT Freeport Indonesia di Kabupaten Mimika, Provinsi Papua. Proceeding Pemaparan Hasil Kegiatan Lapangan Dan Non Lapangan Tahun 2007 Pusat Sumber Daya Geologi.

Prankel SH, Nixon RM, Phillips CJC. 2004. Metaanalysis of feeding trials investigating cadmium accumulation in the livers and kidneys of sheep. Environ. Res. 94 (2): 171-183.

Purwantari N D. 2007. Reklamasi area tailing di pertambangan dengan Tanaman pakan ternak; mungkinkah. Jurnal Wartazoa vol. 17 no. 3 th. 2007

Rahmawati K, Widyastuti M, 2012. Kajian Kualitas limbah cair kegiatan Pertambangan bijih nikel PT. Aneka Tambang tbk, Halmahera Timur, Maluku
Utara.

Ridhowati S. 2013. Mengenal Pencemaran Logam Berat. Jakarta (ID). Graha Ilmu.

Skoog. D. A., Donald M. West, F. James Holler, Stanley R. Crouch, 2000. Fundamentals of Analytical Chemistry .Hardcover: 992 pages, Publisher: Brooks Cole Susilo Y. E B, 2003. Mепијu Keselarasan Lingkungan Memahami Sikap Teologis Manusia Terhadap Pencemaran Lingkungan. Surabaya (ID): Averroes Press.

SNI] Standar Nasional Indonesia. 2009. Batas maksimum cemaran logam berat dalam pangan. SNI 7387:2009. ICS 67.220.20.

Satarug S, Baker JR, Urbenjapol S, Haswell-Elkins MR, Reilly PEB, Williams DJ. 2003 A global perspective on cadmium pollution and toxicity in non-occupationally exposed population. Toxicol Lett.;137:65-83

Taggart MA, Manuel M, Camarero PR, Mateo R. 2011. Should Legislation Regarding Maximum $\mathrm{Pb}$ and $\mathrm{Cd}$ Levels in Human Food also Cover Large Game Meat. J. Environ Int 37:18-25.

Widaningrum, Miskiyah dan Suismono. 2007. Bahaya kontaminasi logam berat dalam sayuran dan alternatif pencegahan cemarannya. Buletin Teknologi Pascapanen Pertanian, Jakarta, 3:12.

WALHI. 2006. Dampak Lingkungan Hidup Operasi Pertambangan Tembaga dan Emas Freeport-Rio Tinto di Papua. 25 Tahun WALHI, Wahana Lingkungan Hidup Indonesia. Jakarta. $119 \mathrm{hlm}$.

[WHO] World Health Organization. 2007. Water for Pharmaceutical Use. In: Quality Assurance of Pharmaceuticals: A Compendium of Guidelines and Related Materials. 2nd Updated Edn. World Health Organisation, Geneva (CH) 2: 170-187.

[WHO] World Health Organization.1996. Evaluation of Certain Food Additives and Contaminants (Thirtythird Report of the Joint FAO/WHO Expert Committee on Food Additives). WHO Technical Report Series No. 776. Geneva:World Health Organization.

Zainal Arifin. 2008. Beberapa Unsur Mineral Esensial Mikro Dalam Sistem Biologi dan Metode Analisisnya. Jurnal Litbang Pertanian, 27(3), 2008 